\title{
Jaks and Stats as therapeutic targets
}

\author{
John J O’Shea, Roberta Visconti, Tammy P Cheng, Massimo Gadina
}

\begin{abstract}
Cytokines have critical functions in regulating immune responses. A large number of these factors bind related receptors termed the Type I and Type II families of cytokine receptors. These receptors activate Janus kinases (Jaks) and Stat family of transcription factors. The essential and specific function of Jaks and Stats is particularly well illustrated by human and mouse mutations. The possibility that these molecules could be targeted to produce novel immunosuppressive compounds is considered in this review.

(Ann Rheum Dis 2000;59(suppl I):i115-i118)
\end{abstract}

Many of the cytokines involved in immune and inflammatory responses bind to receptors designated as Type I cytokine receptors. For instance, the receptors for interleukins (IL) 2 to IL7, IL9 to IL13 and IL15, all belong to this family. Also included in this family are the receptors for ciliary neurotrophic factor, leukaemia inhibitory factor, oncostatin $\mathrm{M}$ and cardiotropin 1. The receptor family also binds hormones, like erythropoietin (EPO), thrombopoietin, prolactin (PRL), growth hormone $(\mathrm{GH})$ and leptin, and colony stimulating factors (CSF), such as granulocyte CSF and granulocyte/macrophage CSF. Closely related are the Type II cytokine receptors that bind interferons (IFNs) and IL10. Both Type I and II receptors have no intrinsic enzymatic activity. However, the membrane proximal segment of these receptors is conserved and is responsible for binding Jaks. Indeed, it has become clear through a variety of studies that Jaks play a pivotal part in signalling via this family of cytokine receptors. Upon ligand binding, Jaks are activated and initiate signalling by phosphorylating cytokine receptors. The phosphorylated receptors, in turn, are recognised by various signalling molecules, one important class of which is the Stat (signal transducer and activator of transcription) family of DNA binding proteins. Stats also have specific and essential functions in cytokine signalling. Consequently, it is of interest to consider these molecules as potential therapeutic targets.

\section{Janus kinases}

The Janus kinase family is a small family of protein tyrosine kinases; only four vertebrate Jaks have been identified (Jak1, Jak2, Jak3 and Tyk2). The essential functions of the Jaks in signalling by interferons and cytokines were first established using a panel of mutagenised cell lines made resistant to the effects of interferons. ${ }^{1}$ Through reconstitution experiments, it was first shown that Jaks are required for inter- feron signalling and it is now recognised that all type I and II cytokine receptors activate various Jaks. ${ }^{2}{ }^{3}$ Some Jaks (Jak1, Jak2 and Tyk2) are used by a variety of cytokine receptors, whereas Jak3 is used only by cytokines whose receptors comprise the common cytokine $\gamma$ chain, $\gamma$ c. The pivotal function of the Jaks is best illustrated in mice or humans deficient in these kinases. The first deficiency of a mammalian Jak was identified in a human disease. ${ }^{45}$ Severe combined immunodeficiency (SCID) comprises various disorders manifested by $\mathrm{T}$ and $\mathrm{B}$ lymphocyte abnormalities, associated with severe infections early in life. The most common form of SCID, X-SCID, is attributable to mutations of $\gamma c$, which results in impaired signalling via all the cytokines that utilise this receptor subunit (IL2, IL4, IL7, IL9 and IL15). As Jak3 associates with $\gamma \mathrm{c}$, the possibility of Jak3 mutations was investigated in selected SCID patients and we demonstrated that mutation of either $\gamma \mathrm{c}$ or Jak3 leads to the same functional defects. Shortly thereafter Jak3 knockout mice were generated, and they, too, have defects of T, B and NK cells; no other defects have been reported. ${ }^{6-9}$ The $\mathrm{T}$ and $\mathrm{B}$ lymphocyte abnormalities in $\gamma_{c}$ and Jak3 deficient mice and humans are principally attributable to the failure of IL7 signalling, as mice and humans with IL7R mutations also have SCID. ${ }^{10}$ In contrast, defective NK development in SCID patients is probably the result of defective IL15 signalling. ${ }^{11} 12$

Unlike Jak3, deficiency of Jak1 and Jak2 results in more diverse abnormalities. ${ }^{13-15}$ Jak1 -/- mice die perinatally, apparently because of impaired neurological development. ${ }^{13}$ Like Jak3 -/- mice, Jak1 knockout mice also have SCID. This is explained by the fact that Jak1 binds the ligand specific subunit of $\gamma_{c}$ using receptors. Other cytokine receptors that require Jak1 include: gp130 cytokine receptors (for IL6, LIF, OSM, CNTF, and IL11) and Type II cytokines receptors (for IL10, IFN $\alpha$, IFN $\beta$, and IFN $\gamma$ ).

In contrast with Jak3 and Jak1 deficient mice, Jak2 knockouts die as embryos because Jak2 is essential for EPO signalling and Jak2 -/mice do not form blood. ${ }^{15}$

The critical function of Jaks is supported by another body of evidence. Specifically, chromosomal translocations involving the 3' region of Jak2 gene and the 5' region of the Tel transcription factor gene have been associated with leukaemia. ${ }^{16-19}$ Experimentally it has been established that uncontrolled Jak2 signalling produced by this fusion is transforming.

At present, the three dimensional structure for any of the Jaks is still lacking, so our understanding of Jak structure is quite limited. Overall conservation of Janus kinases has been 
noted and the regions of homology are termed Janus homology $(\mathrm{JH})$ domains. The C-terminal tyrosine kinase or $\mathrm{JH} 1$ domain is the catalytically active portion of the molecule. Amino terminal to the kinase domain is a segment homologous to a kinase domains but which lacks catalytic activity. This segment is termed the pseudo kinase or $\mathrm{JH} 2$ domain and is unique; no other mammalian tyrosine kinase has such a domain. While it lacks catalytic activity, this domain seems to a have regulatory function. ${ }^{20-22}$ The association with cytokine receptors is mediated by the $\mathrm{N}$-terminus of the Jaks. For Jak3, a relatively small portion of the molecule confers most of its ability to bind $\gamma c{ }^{2324}$ For other Jak/receptor interactions, the segments mediating this interaction may be more extended than those of Jak $3 .^{25} 26$

As Jaks are essential elements in cytokine signalling, it has been widely recognised that these kinases might be reasonable targets for the development of novel immunosuppressants. ${ }^{27}$ Because Jak3 deficiency has such specific defects (that is, limited to lymphoid cells), it has been suggested that this kinase might be a particularly good target. ${ }^{27}$ Conversely, based on the phenotypes of the knockout mice, Jak 1 and Jak 2 would not be expected to be good targets; the toxicity of targeting these kinases might be substantial.

Before answering the question of whether the development of a Jak3 inhibitor is feasible, it is reasonable to ask whether the development of any specific protein kinase inhibitor is attainable. The answer, though, seems clear; $\mathrm{Bcr}-\mathrm{Abl}$, EGFR, HER2, and protein kinase C (PKC) inhibitors are currently in Phase I and II clinical trials. ${ }^{28}$ Moreover, delineating the three dimensional structure of various tyrosine kinases should facilitate the development of specific inhibitors. ${ }^{29-31}$

A number of compounds have been reported to be Jak inhibitors. ${ }^{32-41}$ Exactly how specific they are for Jaks and in particular, Jak3 in vitro and in vivo, has yet to be firmly established. None the less, given their unique structure, it should be possible to generate Jak specific inhibitors. However, developing a Jak3 specific inhibitor may be more challenging. For instance, the most widely tested compound, the tyrphostin AG-490, inhibits both Jak2 and Jak3. The likelihood that a Jak2 inhibitor would cause unacceptable toxicity (for example, cytopenias), seems considerable.

\section{Stats}

After Jaks are activated by cytokine binding to cognate receptors, they phosphorylate receptor subunits, creating docking sites for various signalling molecules. Signal transducers and activators of transcription (Stats), latent cytosolic transcription factors, bind to phosphorylated cytokine receptors via their SH2 domains; different Stats bind to specific cytokine receptors. ${ }^{1242}{ }^{43}$ Stats in turn, are phosphorylated by Jaks, effecting their dimerisation via reciprocal SH2-phosphotyrosine interactions. This leads to their nuclear translocation where they regulate gene transcription. Stats bind two types of DNA motifs, ISREs (IFN stimulated response elements, consensus AGTTTNCNTTTCC) and GAS elements ( $\gamma$ activated sequence, consensus TTCNNNGAA). Thus, as the name implies, Stats serve essential functions in rapidly transducing signals from cytokine receptors to the nucleus, where they bind DNA and regulate gene transcription. These functions are readily explained by Stat structure; indeed in the case of the Stats, we are more fortunate than with the Jaks, as the three dimensional structure of this family of transcription factors has been solved. Stat molecules consist of a central DNA binding domain flanked by a coiled-coiled domain that binds other transcription factors and coactivators. ${ }^{44} 45$ They also have an N-terminal domain involved in dimer-dimer interactions. ${ }^{46}$ C-terminal of the DNA binding domain is a linker domain followed by the $\mathrm{SH} 2$ domain and a conserved site of tyrosine phosphorylation. The C-terminus of the Stats is variable and contains the transcriptional activation domain. Some Stats are also phosphorylated on a conserved serine residue in the transcriptional activation domain; this seems to be mediated by a MAPK family member. Recently several studies have pointed to the role of p38 as the kinase responsible for this modification $^{47-50}$ (Visconti et al submitted data). It is possible that pharmacological inhibitors of p38 might be therapeutically useful to interfere with Stat activation via this mechanism.

There are seven mammalian Stats: Stat1, Stat3, Stat4, Stat5a, Stat5b and Stat6. The critical functions of Stat 1 and Stat2 in transmitting cytokine dependent signals were established through the use of mutagenised cell lines defective in IFN responses; reconstitution of these cell lines with the missing Stat was shown to restore signalling. ${ }^{1}$ Subsequently various knockout mice have been produced, which also substantiate the specific and essential functions of the Stats. Stat 1 -/- mice were found to develop normally but had extreme susceptibility to viral and some bacterial infections $^{52}{ }^{53}$; entirely consistent with the defects seen in IFN $\alpha$ R and IFN $\gamma \mathrm{R}$-/- mice and IFN $\gamma \mathrm{R}$ deficient humans. Stat 1 also seems to be important in regulating apoptosis and its absence is associated with tumorigenesis. ${ }^{54}$

In contrast, gene targeting of Stat3 leads to early embryonic lethality. ${ }^{55}$ Using conditional knockouts, it has been shown that targeting of Stat 3 in myeloid cells has a dramatic effect; these mice have an exaggerated inflammatory response, which seems to be attributable to the failure of IL10 signalling. ${ }^{56}$ Stat 4 -/- mice develop completely normally but have defective cell mediated immune responses and $\mathrm{T}$ helper (Th) 1 differentiation and augmented Th2 development. ${ }^{57}{ }^{58}$ This phenotype is entirely consistent with the abnormalities seen in IL12, IL12R -/- mice, and IL12R deficient humans, demonstrating an important role for Stat 4 in IL12 signalling and Th1 differentiation. Stat6 was originally purified as factor induced by IL4. Accordingly, in contrast with Stat 4 knockouts, Stat6 -/- mice have defective Th2 development. ${ }^{59-61}$ They also have defective 
IgE response after infection with parasites. Importantly, they have attenuates experimentally induced allergic and asthmatic disease. The cytokine IL13 shares a receptor subunit with IL4; IL13 also activates Stat6 and its responses are abrogated in Stat6 -/- mice.

Stat $5 a$ and Stat $5 b$ are $91 \%$ identical and can be activated by the same cytokines; none the less they have specific functions. Stat5a knockout mice have impaired mammary gland development and failure of lactation, whereas Stat $5 \mathrm{~b}$ knockout mice have defective sexually dimorphic growth and growth hormone dependent regulation of liver gene expression. ${ }^{62}{ }^{63} \mathrm{In}$ doubly deficient, Stat $5 \mathrm{a} / 5 \mathrm{~b}$-/- mice, $\mathrm{T}$ cells develop but they are very abnormal; although the cells fail to proliferate in vitro, the mice develop lymphoproliferative disease, suggesting a defect in apoptosis.

From these knockouts, the two most useful targets would seem to be Stat4 and Stat6; inhibitors could block cell mediated immunity and allergic responses respectively. But what would one target in the Stats? Unlike the Jaks, they do not have enzymatic activity. Their major function, of course, is to bind DNA and activate gene transcription and so these properties could be targeted. The crystal structure of the Stats demonstrates that the phosphotyrosine-SH2 interaction is the major contributor to their structure bound to DNA. While logical, attempting to disrupt this interaction seems formidable. Moreover, the precedents for developing such an inhibitor are less clear than those for a kinase inhibitor.

Much progress has been made in the identification of the molecular basis of cytokine action. The elucidation of the Jak/Stat pathway provides a solution to some of the problems of intracellular signalling, comprising surprisingly specific and essential functions. Much remains to be learned about the mechanisms by which cytokine dependent gene regulation occurs and we still have a limited understanding of the complex interplay among the various signalling pathways and the means by which different transcription factors work in concert to regulate gene expression. None the less, the numerous recent advances enable us to define the targets for the development of novel therapies.

1 Darnell JEJ, Kerr IM, Stark GR. Jak-STAT pathways and transcriptional activation in response to IFNs and other extracellular signaling proteins. Science 1994;264:1415.

2 Ihle JN, Witthuhn BA, Quelle FW, Yamamoto K, Silvennoinen O. Signaling through the hematopoietic cytokine noinen O. Signaling through the hematopo
receptors. Annu Rev Immunol 1995;13:369.

3 Leonard WJ, O'Shea JJ. Jaks and STATs: biological implicaLeonard WJ, O'Shea JJ. Jaks and STATs:
tions. Annu Rev Immunol 1998;16:293.

4 Russell S M, Tayebi N, Nakajima H, Riedy MC, Roberts JL, Aman MJ, et al. Mutation of Jak 3 in a patient with SCID essential role of Jak3 in lymphoid development. Science 1995;270:797

5 Macchi P, Villa A, Gillani S, Sacco MG, Frattini A, Porta F et al. Mutations of Jak-3 gene in patients with autosoma severe combined immune deficiency (SCID). Nature 1995;377:65

6 Nosaka T, van Deursen JM, Tripp RA, Thierfelder WE, Witthuhn BA, McMickle AP, et al. Defective lymphoid development in mice lacking Jak3. Science 1995;270:800.

7 Thomis DC, Gurniak CB, Tivol E, Sharpe AH, Berg LJ. Defects in B lymphocyte maturation and T lymphocyte activation in mice lacking Jak3. Science 1995;270:794.

8 Park SY, Saijo K, Takahashi T, Osawa M, Arase H, Hirayama N, et al. Developmental defects of lymphoid cells in Jak3 kinase-deficient mice. Immunity 1995;3:771.

9 Baird AM, Thomis DC, Berg LJ. T cell development and Baird AM, Thomis DC, Berg LJ. T cell development and
activation in Jak3-deficient mice. J Leukoc Biol 1998;63: 669 .
10 Puel A, Ziegler SF, Buckley RH, Leonard WJ. Defective IL7R expression in $\mathrm{T}(-) \mathrm{B}(+) \mathrm{NK}(+)$ severe combined immunodeficiency. Nat Genet 1998;20:394.

11 Lodolce JP, Boone DL, Chai S, Swain RE, Dassopoulos T, Trettin S, et al. IL-15 receptor maintains lymphoid homeostasis by supporting lymphocyte homing and proliferation. Immunity 1998;9:669.

12 Kennedy MK, Glaccum M, Brown SN, Butz EA, Viney JL, Embers $\mathrm{M}$, et al. Reversible defects in natural killer and memory CD8 $\mathrm{T}$ cell lineages in interleukin 15-deficient mice. J Exp Med 2000;191:771.

13 Rodig SJ, Meraz MA, White JM, Lampe PA, Riley JK, et al. Disruption of the Jak1 gene demonstrates obligatory and nonredundant roles of the Jaks in cytokine-induced biologic responses. Cell 1998;93:373.

14 Neubauer H, Cumano A, Muller M, Wu H, Huffstadt U, Pfeffer K. Jak2 deficiency defines an essential developmen397.

15 Parganas E, Wang D, Stravopodis D, Topham J, Marine JC, Teglund S, et al. Jak2 is essential for signaling through a variety of cytokine receptors. Cell 1998;93:385.

16 Peeters P, Raynaud SD, Cools J, Wlodarska I, Grosgeorge J, Philip P, et al. Fusion of TEL, the ETS-variant gene 6 (ETV6), to the receptor-associated kinase JAK2 as a result of $\mathrm{t}(9 ; 12)$ in a lymphoid and $\mathrm{t}(9 ; 15 ; 12)$ in a myeloid leukemia. Blood 1997;90:2535.

17 Lacronique V, Boureux A, Valle VD, Poirel H, Quang CT, Mauchauffe $M$, et al. A TEL-JAK2 fusion protein with constitutive kinase activity in human leukemia. Science 1997;278:1309.

18 Ho JM, Beattie BK, Squire JA, Frank DA, Barber DL. Fusion of the ets transcription factor TEL to Jak2 results in constitutive Jak-Stat signaling. Blood 1999;93:4354.

19 Lacronique V, Boureux A, Monni R, Dumon S, Mauchauffe $\mathrm{M}$, Mayeux $\mathrm{P}$, et al. Transforming properties of chimeric TEL-JAK proteins in $\mathrm{Ba} / \mathrm{F} 3$ cells. Blood $2000 ; 95: 2076$.

20 Chen M, Cheng A, Candotti F, Zhou Y-J, Hymel A, Fasth A, et al. Complex effects of naturally occurring mutations in the JAK3 pseudokinase domain: evidence for interactions between the kinase and pseudokinase domains. Mol Cell Biol 2000;20:947-56.

21 Candotti F, Oakes SA, Johnston JA, Giliani S, Schumacher RF, Mella $\mathrm{P}$, et al. Structural and functional basis for AK3-deficient severe combined immunodeficiency. Blood 1997;90:3996.

22 Saharinen P, Takaluoma K, Silvennoinen O. Regulation of the Jak2 tyrosine kinase by its pseudokinase domain. Mol Cell Biol 2000;20:3387.

23 Chen M, Cheng A, Chen YQ, Hymel A, Hanson EP, Kimmel L, et al. The amino terminus of JAK3 is necessary and sufficient for binding to the common gamma chain and confers the ability to transmit interleukin 2-mediated confers the ability to transmit interleukin $2-m$
signals. Proc Natl Acad Sci USA 1997;94:6910.

24 Cacalano NA, Migone TS, Bazan F, Hanson EP, Chen M, Candotti F, et al. Autosomal SCID caused by a point mutation in the N-terminus of Jak3: mapping of the Jak3-receptor interaction domain. EMBO J 1999;18:1549.

25 Yan H, Piazza F, Krishnan K, Pine R, Krolewski JJ. Definition of the interferon-alpha receptor-binding domain on the TYK2 kinase. J Biol Chem 1998;273:4046.

26 Richter MF, Dumenil G, Uze G, Fellous M, Pellegrini S. Specific contribution of tyk $2 \mathrm{JH}$ regions to the binding and the expression of the interferon alpha/beta receptor component IFNAR1. J Biol Chem 1998;273:24723.

27 Waldmann TA, O'Shea J. The use of antibodies against the IL-2 receptor in transplantation. Curr Opin Immunol 1998;10:507.

28 Druker BJ, Lydon NB. Lessons learned from the development of an abl tyrosine kinase inhibitor for chronic myelognous leukemia. J Clin Invest 2000;105:3.

29 Mohammadi M, McMahon G, Sun L, Tang C, Hirth P, Yeh $\mathrm{BK}$, et al. Structures of the tyrosine kinase domain of fibroblast growth factor receptor in complex with inhibitors. Science 1997;276:955.

30 Mohammadi M, Froum S, Hamby JM, Schroeder MC, Panek RL, Lu GH, et al. Crystal structure of an angiogenesis inhibitor bound to the FGF receptor tyrosine kinase domain. EMBO J 1998; 17:5896.

31 Meydan N, Grunberger T, Dadi H, Shahar M, Arpaia E, Lapidot Z,et al. Inhibition of acute lymphoblastic leukaemia by a Jak-2 inhibitor. Nature 1996;379:645.

32 Bright JJ, Du C, Sriram S. Tyrphostin B42 inhibits IL-12-induced tyrosine phosphorylation and activation of Janus kinase- 2 and prevents experimental allergic encephalomyelitis. J Immunol 1999;162:6255.

33 Kirken RA, Erwin RA, Taub D, Murphy WJ, Behbod F, Wang L, et al. Tyrphostin AG-490 inhibits cytokinemediated JAK3/STAT5a/b signal transduction and cellular proliferation of antigen-activated human T cells. J Leukoc Biol 1999;65:891.

34 Wang LH, Kirken RA, Erwin RA, Yu CR, Farrar WL. JAK3, STAT, and MAPK signaling pathways as novel molecular targets for the tyrphostin AG-490 regulation of IL-2mediated T cell response. J Immunol 1999;162:3897.

35 Elder RT, Xu X, Williams JW, Gong H, Finnegan A, Chong AS. The immunosuppressive metabolite of leflunomide, A77 1726, affects murine T cells through two biochemical mechanisms. J Immunol 1997;59:22.

36 Siemasko K, Chong AS, Jack HM, Gong H, Williams JW, Finnegan A. Inhibition of JAK 3 and STAT 6 tyrosine phospinnegan A. Inhibition of JAK 3 and STAT 6 tyrosine phosphorylation by the immunosuppressive drug leflunomide 1581 . 
37 Sudbeck EA, Liu XP, Narla RK, Mahajan S, Ghosh S, Mao $\mathrm{C}$, et al. Structure-based design of specific inhibitors of Janus kinase 3 as apoptosis-in
Clin Cancer Res 1999;5:1569.

38 Malaviya R, Zhu D, Dibirdik I, Uckun FM. Targeting Janus kinase 3 in mast cells prevents immediate hypersensitivity reactions and anaphylaxis [published erratum appears in J
Biol Chem 1999;274:38276]. J Biol Chem 1999;274:27028.

39 Uckun FM, Ek O, Liu XP, Chen CL. In vivo toxicity and pharmacokinetic features of the janus kinase 3 inhibitor WHI-P131 [4-(4'hydroxyphenyl)-amino-6,7- dimethoxyquinazoline]. Clin Cancer Res 1999;5:2954

40 Trieu VN, Liu R, Liu XP, Uckun FM. A specific inhibitor of janus kinase- 3 increases survival in a transgenic mouse model of amyotrophic lateral sclerosis. Biochem Biophys Res Commun 2000;267:22.

41 O'Shea J J. Jaks, STATs, cytokine signal transduction, and immunoregulation: Are we there yet? Immunity 1997;7:1.

42 Hoey T, Grusby MJ. STATs as mediators of cytokineinduced responses. Adv Immunol 1999;71:145.

43 Chen X, Vinkemeier U, Zhao Y, Jeruzalemi D, Darnell JEJ, Kuriyan J. Crystal structure of a tyrosine phosphorylated STAT-1 dimer bound to DNA. Cell 1998;93:827.

Groner B, Muller CW. Three-dimensional structure of the Stat3beta homodimer bound to DNA. Nature 1998;394:145

45 Vinkemeier U, Moarefi I, Darnell JEJ, Kuriyan J. Structure of the amino-terminal protein interaction domain of STAT-4. Science 1998;279:1048.

46 Bode JG, Gatsios P, Ludwig S, Rapp UR, Haussinger D, Heinrich PC, et al. The mitogen-activated protein (MAP) kinase p38 and its upstream activator MAP kinase kinase 6 are involved in the activation of signal transducer and acti1999;274:30222.

47 Zauberman A, Zipori D, Krupsky M, Ben-Levy R. Stress activated protein kinase $\mathrm{p} 38$ is involved in IL-6 induced transcriptional activation of STAT3. Oncogene 1999;18: transcrip 3886.

48 Kovarik P, Stoiber D, Eyers PA, Menghini R, Neininger A, Gaestel $M$, et al. Stress-induced phosphorylation of STAT1
at Ser727 requires p38 mitogen- activated protein kinase at Ser727 requires p38 mitogen- activated protein kinase whereas IFN-gamma uses a different sign
Proc Natl Acad Sci USA 1999;96:13956.

49 Goh KC, Haque SJ, Williams BR. p38 MAP kinase is required for STAT1 serine phosphorylation and transcriptional activation induced by interferons. EMBO J 1999;18: 5601 .
50 Durbin JE, Hackenmiller R, Simon MC, Levy DE. Targeted disruption of the mouse Stat 1 gene results in compromised innate immunity to viral disease. Cell 1996;84:443.

51 Meraz MA, White JM, Sheehan KC, Bach EA, Rodig SJ, Dighe AS, et al. Targeted disruption of the Stat 1 gene in mice reveals unexpected physiologic specificity in the JAKSTAT signaling pathway. Cell 1996;84:431.

52 Kaplan DH, Shankaran V, Dighe AS, Stockert E, Aguet M, Old LJ, et al. Demonstration of an interferon gammadependent tumor surveillance system in immunocompetent mice. Proc Natl Acad Sci USA 1998;95:7556.

53 Takeda K, Noguchi K, Shi W, Tanaka T, Matsumoto M, Yoshida N, et al. Targeted disruption of the mouse Stat3 gene leads to early embryonic lethality. Proc Natl Acad Sci USA 1997;94:3801.

54 Takeda K, Clausen BE, Kaisho T, Tsujimura t, Terada N, et al. Enhanced Th1 activity and development of chronic enterocolitis in mice devoid of Stat 3 in macrophages and neutrophils. Immunity 1999;10:39.

55 Kaplan MH, Sun YL, Hoey T, Grusby MJ. Impaired IL-12 responses and enhanced development of Th2 cells in Stat4-deficient mice. Nature 1996;382:174.

56 Thierfelder WE, van Deursen JM, Yamamoto K, Tripp RA, Sarawar SR, Carson RT, et al. Requirement for Stat 4 in interleukin-12-mediated responses of natural killer and $\mathrm{T}$ cells. Nature 1996;382:171.

57 Kaplan MH, Schindler U, Smiley ST, Grusby MJ. Stat6 is required for mediating responses to IL-4 and for development of Th2 cells. Immunity 1996;4:313.

58 Shimoda K, van Deursen J, Sangster MY, Sarawar SR, Carson RT, Tripp RA, et al. Lack of IL-4-induced Th2 response and IgE class switching in mice with disrupted Stat6 gene. Nature 1996;380:630.

59 Takeda K, Tanaka T, Shi W, Matsumoto M, Minami M, Kashiwamura S, et al. Essential role of Stat6 in IL-4 signalling. Nature 1996;380:627.

60 Liu X, Robinson GW, Wagner KU, Garrett L, WynshawBoris A, Hennighausen L. Stat5a is mandatory for adult mammary gland development and lactogenesis. Genes Dev 1997;11:179

61 Udy GB, Towers RP, Snell RG, Wilkins RJ, Park SH, Ram $\mathrm{PA}$, et al. Requirement of STAT5b for sexual dimorphism of body growth rates and liver gene expression. Proc Natl Acad Sci USA 1997;94:7239. 